\title{
Reduction in Acetylcholine Release in the Hippocampus of Dopamine D5 Receptor-Deficient Mice
}

\author{
François Laplante ${ }^{1,2}$, David R Sibley ${ }^{4}$ and Rémi Quirion*,1,2,3 \\ 'Douglas Hospital Research Centre, LaSalle, Verdun, QC, Canada; ²Department of Pharmacology/Therapeutics, McGill University, Montréal, QC, \\ Canada; ${ }^{3}$ Department of Psychiatry, McGill University, Montréal, QC, Canada; ${ }^{4}$ National Institute of Neurological Disorders and Stroke, National \\ Institute of Health, Bethesda, MA, USA
}

\begin{abstract}
Activation of the dopamine $D_{1}$-like receptor stimulates acetylcholine (ACh) release in the hippocampus, apparently through the molecularly defined d5 receptor. In the present study, we used a transgenic mouse completely deprived of functional $\mathrm{d} 5$ receptor (d5-/-) to confirm the role and elucidate the possible function of the d5 receptor subtype on hippocampal cholinergic neurotransmission. ACh release was measured using in vivo microdialysis in the mouse dorsal hippocampus of 4 months old homozygous $(\mathrm{d} 5-/-)$, heterozygous $(\mathrm{d} 5+/-)$, and the wild-type $(\mathrm{d} 5+/+)$ littermates. Using the no net flux technique, a significant reduction in basal hippocampal ACh level was found in the $\mathrm{d} 5-1-$ compared to $\mathrm{d} 5+1-$ and $\mathrm{d} 5+1+$ mice. Moreover, the administration of SKF 38393, a D,-like receptor agonist, systemically (2.0 and $10.0 \mathrm{mg} / \mathrm{kg}$ ip), or locally through the dialysis probe ( 10 and $50 \mu \mathrm{M})$, produced a dose-dependent enhancement of ACh release in the $\mathrm{d} 5+1+$, a moderate stimulation in the $\mathrm{d} 5+1-$ but had no effect in the $\mathrm{d} 5-1-$ mice. Quantitative receptor autoradiography revealed significant increases in $M_{1}$-like but not in $M_{2}$-like muscarinic receptor binding sites in the hippocampal formation. These results confirm and extend the role of the d5 receptor in the modulation of hippocampal ACh release and provide evidence for long-term alteration of hippocampal cholinergic neurotransmission resulting from the absence of the $\mathrm{d} 5$ receptors including chronically reduced $A C h$ release and change in $M_{1}$-like receptor levels.

Neuropsychopharmacology (2004) 29, I620- |627, advance online publication, 2 I April 2004; doi:| 0.1038/sj.npp. I 300467
\end{abstract}

Keywords: microdialysis; muscarinic receptor; receptor autoradiography; dopamine transgenic mouse

\section{INTRODUCTION}

Dopamine (DA) exerts a modulatory role on acetylcholine (ACh) release in the hippocampus (Day et al, 2001; Hersi et al, 1995a,b). Interactions between these two neurotransmitter systems play key roles in learning and memory (Levin et al, 1990) and these systems, particularly the cholinergic innervation, are severely affected in Alzheimer's Disease (Araujo et al, 1988; Auld et al, 2002; Davies and Maloney, 1976; Perry et al, 1992). Hippocampal cholinergic nerve terminals originate from the medial septum and the vertical limb of the diagonal band of Broca and project to the hippocampal formation via the fimbria fornix (Mesulam et al, 1983; Woolf, 1991). The hippocampus also receives dopaminergic projections arising mainly from the ventral tegmental area with little contribution of the substantia nigra, pars compacta (Gasbarri et al, 1994; Verney et al, 1985).

*Correspondence: Dr R Quirion, Douglas Hospital Research Centre, 6875 boul. LaSalle, Verdun QC, Canada H4H IR3, Tel: + | 51476 | 6I3I (ext 2934), Fax: + I 5147623034 ,

E-mail: quirem@douglas.mcgill.ca

Received 20 December 2003; revised 18 February 2004; accepted I5 March 2004

Online publication: 22 March 2004 at http://www.acnp.org/citations/ Npp03220403569/default.pdf
Numerous studies demonstrated that DA stimulates hippocampal ACh release through the activation of $\mathrm{D}_{1}$-like receptors(Day and Fibiger, 1994; Imperato et al, 1993), most probably through receptors located on hippocampal cholinergic nerve terminals (Hersi et al, 1995a). Moreover, behavioral studies revealed that peripheral administration of a $\mathrm{D}_{1}$-like agonist improved cognitive performance in rats (Steele et al, 1996, 1997), reduced age-related deficits in spatial memory in mice (Bach et al, 1999), and attenuated learning deficits in aged memory impaired rats possibly through the stimulation of hippocampal ACh release (Hersi et al, 1995b).

The $\mathrm{D}_{1}$-like receptor subfamily includes the molecularly defined $\mathrm{d} 1$ and $\mathrm{d} 5$ subtypes (Dearry et al, 1990; Sunahara et al, 1990, 1991; Zhou et al, 1990), which are both expressed in the hippocampus (Bergson et al, 1995; Tiberi et al, 1991). These two subtypes share approximately $50 \%$ sequence homology ( $80 \%$ in the transmembrane domains), which translates into a highly similar pharmacological profile (Seeman and Van Tol, 1993; Sunahara et al, 1991; Tiberi et al, 1991). No drugs are currently able to discriminate between $\mathrm{d} 1$ and $\mathrm{d} 5$ receptors. Recently, an antisense oligonucluotide approach revealed that the d5 (but not d1) receptor was the subtype likely involved in the modulation of hippocampal ACh release (Hersi et al, 2000). 
In the present study, we used an in vivo microdialysis technique in mice lacking functional d5 receptors (d5-l-) to elucidate further the role of the receptor subtype in hippocampal ACh release. The results reported here confirm the tonic role of the $\mathrm{d} 5$ receptor in the dopaminergic modulation of hippocampal ACh release and demonstrated long-term alterations in $\mathrm{M}_{1}$-like muscarinic receptors in the knockout animal model.

\section{MATERIALS AND METHODS}

\section{Materials}

The d5-/- mouse with a genetic background of $129 / \mathrm{SvJ} 1$ and C57BL/6J was generated as described earlier (Hollon et al, 2002) and provided by one of the authors (D Sibley). Immunohistochemical detection of $\mathrm{d} 5$ receptors revealed that the frontal cortex in the $\mathrm{d} 5-/-$ mouse was, as expected, completely devoid of this receptor (Hollon et al, 2002). Animals were reproduced in our animal facilities by standard inbreeding. Females were isolated to give birth and pups were weaned at postnatal day 21 . The genotype of each mouse was determined using a PCR technique as previously described (Hollon et al, 2002). Experiments were performed in homozygous $\mathrm{d} 5-I-$, heterozygous $(\mathrm{d} 5+I-)$, and wild-type $(\mathrm{d} 5+I+)$ littermates. Homozygous $\mathrm{d} 5-I-$ mice are viable, develop normally and are fertile and capable of reproduction (Hollon et al, 2002). These animals were housed two to six per cage at room temperature and on a 12-h light/dark schedule. The animals were fed ad libidum with standard lab chow and tap water up to the time of the experiments, according to protocols and guidelines approved by the McGill University Animal Care Committee and the Canadian Council for Animal Care (CCAC).

Ketamine, xylazine, and acepromazine were obtained from Vetrepharm (Belleville, ON), Novopharm (Toronto, $\mathrm{ON}$ ), and Wyert-Ayerst (Montréal, PQ), respectively. The dialysis membrane used was made from AN69 Hospal Industry (molecular weight cut off $60000 \mathrm{Da}$, i.d. $=0.22 \mathrm{~mm}$, o.d. $=0.31 \mathrm{~mm}$; Hospal, Lyon, France). The membrane was covered with epoxy glue along its whole length except for $4 \mathrm{~mm}$ corresponding to the area of dialysis. 1-Phenyl2,3,4,5-tetrahydro-(1H)-3-benzazepine-7,8-diol (SKF 38393) and neostigmine bromide were obtained from Sigma RBI (Oakville, ON).

The microliter syringe pump was from Harvard Apparatus Inc. (South Natick, MA), ESA 580 HPLC dual piston pump from ESA (Chelmford, MA), CMA 260 degasser from Cargenie Medicin (Stockholm, Sweden), Lichrosorb $\mathrm{NH}_{2}$ $(10 \mu \mathrm{m})$ was from Merck (Darmstadt, Germany), platinum and $\mathrm{Ag} / \mathrm{AgCl}$ reference electrodes (Antec VT-03/Decade) from Decade (Leiden, the Netherlands), and column hardware and packing materials were from Chrompack (Raritan, MA). $\left[{ }^{3} \mathrm{H}\right] \mathrm{SCH} 23390(73.0 \mathrm{Ci} / \mathrm{mmol}),\left[{ }^{3} \mathrm{H}\right]$ pirenzepine $(79.3 \mathrm{Ci} / \mathrm{mmol})$, and $\left[{ }^{3} \mathrm{H}\right]$ AFDX-384 $(137.0 \mathrm{Ci} / \mathrm{mmol})$ were from New England Nuclear (Boston MA) and tritiumsensitive films from Amersham (Oakville, ON).

All other reagents and chemical for the in vivo microdialysis, HPLC, and receptor autoradiography were obtained from Sigma Chemical Co (St Louis, MO).

\section{Probe Implantation}

The microdialysis probe was implanted in the dorsal hippocampus according to procedures described by our group for rats with minor modifications (Day et al, 2001; Hersi et al, 1995a; Kitaichi et al, 1999). Male mice, 4-month old, were anesthetized using a mix of ketamine $(100 \mathrm{mg} / \mathrm{kg})$, zylazine $(20 \mathrm{mg} / \mathrm{kg})$, and acepromazine $(10 \mathrm{mg} / \mathrm{kg})$ administered intramuscularly. Animals were placed in a stereotaxic apparatus. The skull was uncovered and lateral muscle displaced to expose parietal bone. One hole (about $2 \mathrm{~mm}$ diameter) was drilled on each side. The dialysis transverse probes were inserted through the holes at the level of the dorsal hippocampus, $2.2 \mathrm{~mm}$ posterior to bregma and $2.0 \mathrm{~mm}$ below the surface of the skull (Franklin and Paxinos, 1997). After insertion, the ends of the dialysis tube were connected to a stainless steal cannulae using epoxy glue. Steel cannulae were secured on the top of the skull using dental cement and fixed on the skull with a screw. In vivo microdialysis were performed $48 \mathrm{~h}$ after surgery.

\section{In Vivo Microdialysis}

At the beginning of each dialysis experiment, animals were placed in a lidless cage and the probes connected to a microliter syringe pump in a manner as to allow mice to move freely in the cage. The dialysis probe was perfused at a constant rate of $2.5 \mu \mathrm{l} / \mathrm{min}$ with a cerebrospinal fluid-like solution containing (in $\mathrm{mM}$ ) $\mathrm{NaCl} 123, \mathrm{KCl} 3, \mathrm{CaCl}_{2}$ 1.3, $\mathrm{MgCl}_{2} 1 \mathrm{NaHCO}_{3} 23$, and sodium phosphate buffer $1 \mathrm{pH}$ 7.4. Neostigmine bromine $(10 \mathrm{nM})$, an acetylcholinesterase inhibitor, was added to the solution. After a $1 \mathrm{~h}$ washout period, 20 min dialysate fractions were collected. SKF 38393 (2.0 and $10.0 \mathrm{mg} / \mathrm{kg}$ in sodium chloride $0.9 \%$ solution) was administered by intraperitoneal (i.p.) injection or locally (10 or $50 \mu \mathrm{M})$ through the dialysis probe. Each animal was dialysed once and tested for only one pharmacological treatment.

\section{No Net Flux Method}

The no net flux microdialysis technique is used to determine the in vivo extracellular concentration of a neurotransmitter (Day et al, 2001; Justice, 1993). Another group of animals was perfused with the same cerebrospinal fluid-like solution used in the former experiment without neostigmine bromine but containing a known concentration of $\mathrm{ACh}(2.5,5.0,7.5$, or $10.0 \mathrm{nM})\left[\mathrm{ACh}_{\text {in }}\right]$ perfused through the dialysis tube at a constant rate of $5 \mu \mathrm{l} / \mathrm{min}$. When $\left[\mathrm{ACh}_{\text {in }}\right]$ is lower than that surrounding the probe, ACh will flow down its concentration gradient into the probe, increasing the resultant $\mathrm{ACh}$ concentration measured in the dialysate $\left[\mathrm{ACh}_{\text {out }}\right]$. When $\left[\mathrm{ACh}_{\text {in }}\right]$ is higher than that surrounding the probe, $\mathrm{ACh}$ will flow out of the probe and $\left[\mathrm{ACh}_{\text {out }}\right]$ will be smaller than $\left[\mathrm{ACh}_{\text {in }}\right]$. By plotting $\left[\mathrm{ACh}_{\text {in-out }}\right]$ as a function of $\left[\mathrm{ACh}_{\text {in }}\right]$, the point where the line cross the $x$-axis can be extrapolated (ie where $\left[\mathrm{ACh}_{\text {in-out }}\right]=0$, where there is no net flux) to give a measure of [ACh] surrounding the probe. For this experiment, dialysate samples were collected every $20 \mathrm{~min}$ and assayed for ACh content. 


\section{ACh Measurement}

ACh content in dialysate fractions was determined using HPLC separation, postcolumn enzymatic reaction, and electrochemical detection (Day et al, 2001). ACh was separated from other molecules in the dialysate on a reverse phase column $(75 \times 2.1 \mathrm{~mm})$ pretreated with sodium lauryl sulfate. From this column, the eluate then passes through an enzyme reactor $(10 \times 2.1 \mathrm{~mm})$ containing acetylcholinesterase (AChE; EC 3.1.1.7; type VI-S) and choline oxidase (EC 1.1.3.17) covalently bound to gluteraldehyde-activated Lichrosorb $\mathrm{NH}_{2}$. The separated ACh reacts with the enzymes to give stoichiometric yield of hydrogen peroxide, which is electrochemically detected with a platinum electrode at a potential of $+500 \mathrm{mV} v s$ an $\mathrm{Ag} / \mathrm{AgCl}$ reference electrode. The mobile phase consist of a $0.2 \mathrm{M}$ aqueous potassium phosphate buffer, $\mathrm{pH}$ 8.0, containing $1 \mathrm{mM}$ tetramethylammonium hydroxide and is delivered at $0.35-0.45 \mathrm{ml} / \mathrm{min}$ and is degassed online. ACh elutes at $\sim 4 \mathrm{~min}$, and the best detection limit of the assay is $\sim 10 \mathrm{fmol} /$ injection. Sample concentrations were calculated by comparison with known standards.

\section{Receptor Autoradiography}

Animals were killed by decapitation. Brains were removed and frozen in 2-methylbutane at $-40^{\circ} \mathrm{C}$ and stored at $-80^{\circ} \mathrm{C}$. Coronal brain sections $(20 \mu \mathrm{m})$ were cut at $-18^{\circ} \mathrm{C}$ on a cryostat, thaw-mounted on gelatin-coated slides and stored at $-80^{\circ} \mathrm{C}$ until use.

D1-like DA receptors. D1-like receptor binding sites were visualized using $\left[{ }^{3} \mathrm{H}\right] \mathrm{SCH} 23390$ as described before (Flores et al, 1996). Brain sections were preincubated for $10 \mathrm{~min}$ at room temperature in buffer containing $50 \mathrm{mM}$ Tris- $\mathrm{HCl}, \mathrm{pH}$ 7.4, $154 \mathrm{mM} \mathrm{NaCl}, 1 \mathrm{mM}$ EDTA, and $0.1 \%$ of bovine serum albumin. Sections were incubated at room temperature in the same buffer containing $2 \mathrm{nM}\left[{ }^{3} \mathrm{H}\right] \mathrm{SCH} 23390$ and $30 \mathrm{nM}$ ketanserin to mask possible binding of the ligand to serotonergic 5-HT2 sites. Consecutive sections were also incubated in presence of $1 \mu \mathrm{M}(+)$-butaclamol to ascertain the specificity of the binding. Incubations were terminated by dipping slides into ice-cold buffer followed by two consecutive $10 \mathrm{~min}$ washes in buffer and a rapid dip into ice-cold distillated water. Slices were air-dried and autoradiograms were generated by apposing sections alongside tritium standards to tritium-sensitive films for 15 days.

Muscarinic receptors. Muscarinic $\mathrm{M}_{1}$-like and $\mathrm{M}_{2}$-like receptor binding sites were visualized using $\left[{ }^{3} \mathrm{H}\right]$ pirenzepine and $\left[{ }^{3} \mathrm{H}\right]$ AFDX-384, respectively, as described elsewhere (Vaucher et al, 2002). Brain sections were preincubated for $10 \mathrm{~min}$ in Krebs buffer $(\mathrm{NaCl} 120 \mathrm{mM}$; $\mathrm{KCl} \quad 4.7 \mathrm{mM} ; \mathrm{CaCl}_{2} 2.5 \mathrm{mM} ; \mathrm{KH}_{2} \mathrm{PO}_{4} \quad 1.2 \mathrm{mM} ; \mathrm{MgSO}_{4}$ $1.2 \mathrm{mM}$; glucose $5.6 \mathrm{mM} ; \mathrm{NaHCO}_{3} 25 \mathrm{mM}, \mathrm{pH} 7.4$ ) at room temperature before a 60 -min incubation into the same buffer containing either $10 \mathrm{nM}\left[{ }^{3} \mathrm{H}\right]$ pirenzepine or $2 \mathrm{nM}$ $\left[{ }^{3} \mathrm{H}\right]$ AFDX-384. Consecutive sections were incubated in the presence of atropine $(1 \mu \mathrm{M})$ to ascertain the specificity of the labelling. Sections were rinsed three times ( 4 min each) in ice-cold Tris- $\mathrm{HCl}$ buffer $(50 \mathrm{mM}, \mathrm{pH} 7.4)$ followed by a rapid dip in ice-cold distilled water to removed buffer salts

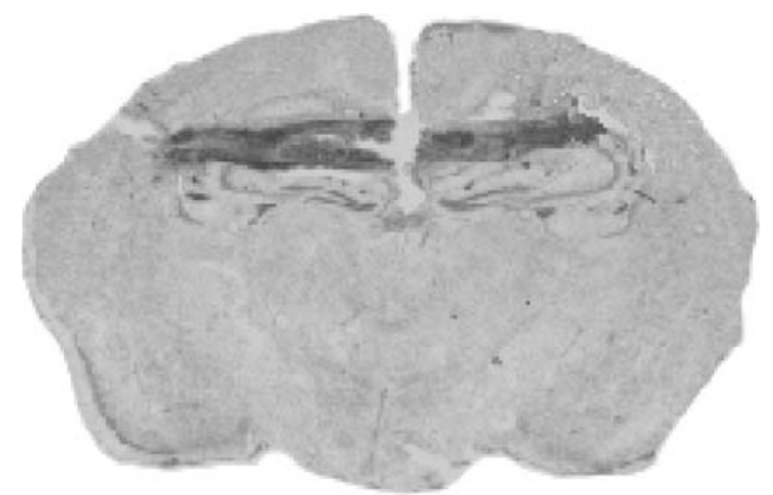

Figure I Histological representation of a coronal section from a 4-month old mouse brain stained with cresyl violet demonstrating the location of the microdialysis probe into the dorsal hippocampus.

and sections were air-dried. Autoradiograms were generated by apposing sections alongside tritium standards to tritium-sensitive films for 15 days for $\left[{ }^{3} \mathrm{H}\right]$ pirenzepine binding and 3 weeks for $\left[{ }^{3} \mathrm{H}\right]$ AFDX-384 binding.

Films were developed as described before (Quirion et al, 1981 ) and the specific labelling was quantified ( $\mathrm{fmol} / \mathrm{mg}$ tissues wet weight) using a computer-assisted microdensitometric image analysing system (MCID System, Imaging Research Inc., St Catherines, Ontario, Canada).

\section{Histology}

After each in vivo microdialysis experiment, animals were killed by cervical dislocation and brains were removed and frozen in 2-methylbutane at $-40^{\circ} \mathrm{C}$ and stored at $-80^{\circ} \mathrm{C}$. Then, $20 \mu \mathrm{m}$ coronal sections were mounted onto gelatincoated slides and stained with cresyl violet to confirm probe location into both dorsal hippocampi (Figure 1). Animals whose probe was not implanted in the appropriate area were excluded from the study.

\section{Statistical Analysis}

For in vivo microdialysis experiments, data were analyzed by a repeated measure three-way analysis of variance (ANOVA), for the main effect of genotype, main effect of pharmacological treatments, main effect of time as repeated measures, and interaction between these three factors. Post hoc Bonferonni analyses were conducted when appropriate. For the no net flux experiments, basal ACh release and for receptor autoradiography, significant differences between experimental groups were determined using one-way ANOVA with post hoc Dunnett's multiple comparisons with the $\mathrm{d} 5+I+$ genotype, $p<0.05$ being considered significant.

\section{RESULTS}

\section{Determination of Basal Hippocampal ACh Level}

Using the no net flux technique, we established the extracellular concentration of ACh into the dorsal hippocampus to $4.4 \pm 0.2 \mathrm{nM}$ for the $\mathrm{d} 5+I+\quad(n=11)$, $4.0 \pm 0.2 \mathrm{nM}$ for $\mathrm{d} 5+I-(n=7)$, and $2.8 \pm 0.1 \mathrm{nM}$ for the $\mathrm{d} 5-I-(n=11)$ mice (Figure 2). A significant reduction of 


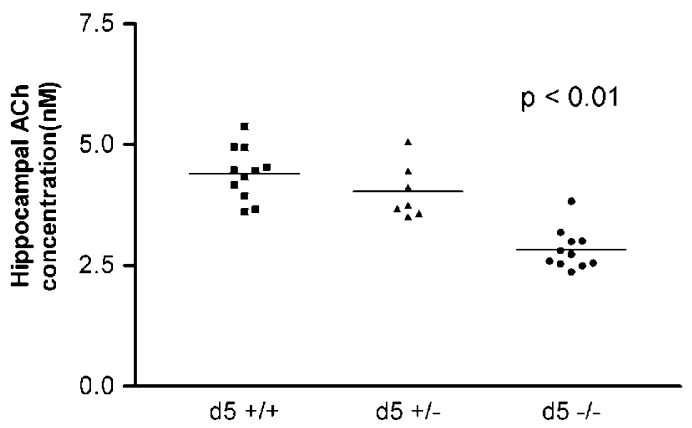

Figure 2 Extracellular levels of $A C h$ as determined using the no net flux method in dopamine d5 knockout (d5-/-) heterozygous (d5 $+/-)$ and wild-type $(\mathrm{d} 5+/+)$ mice. Each point represents individual animals. Post hoc analysis revealed significant differences between $\mathrm{d} 5+1+$ and $\mathrm{d} 5-1-$ $(p<0.01)$

basal hippocampal ACh level was hence observed in $\mathrm{d} 5-1-$ mice compared to $\mathrm{d} 5+I+$ controls $\quad\left(\mathrm{F}_{(2,26)}=28.43\right.$, $p<0.01)$, whereas $\mathrm{d} 5+/-$ had no significant reduction compared to the wild-type mice.

Before pharmacological treatments, the average basal efflux of ACh was $274 \pm 28 \mathrm{fmol} / 50 \mu$ l dialysate in $\mathrm{d} 5+/+$ $(n=31), 239 \pm 19 \mathrm{fmol} / 50 \mu \mathrm{l}$ dialysate in $\mathrm{d} 5+/-(n=29)$, and $180 \pm 18 \mathrm{fmol} / 50 \mu \mathrm{l}$ dialysate in $\mathrm{d} 5-/-(n=30)$. In accordance with data obtained using the no net flux method, a significant reduction of basal hippocampal ACh release was observed in $\mathrm{d} 5-1-$ mice compared to $\mathrm{d} 5+I+$ controls $\left(\mathrm{F}_{(2,89)}=4.44, p=0.015\right)$.

\section{Effect of SKF 38393, a $\mathrm{D}_{1}$-like Agonist}

Three-way ANOVA revealed significant interaction between the main effects of genotype, treatment, and time $\left(\mathrm{F}_{(44,539)}=2.70, p<0.0001\right)$. Saline administration slightly increased ACh release likely as a consequence of the animal handling. However, no significant differences in saline effects were observed between the three animal genotypes (Figure 3a). The systemic administration of SKF 38393 (2.0 and $10.0 \mathrm{mg} / \mathrm{kg}$ ip) differentially affected ACh release in the hippocampus of the animal subgroups studied here. The $\mathrm{D}_{1}$-like agonist increased hippocampal ACh release to a greater extent at 20,40 , and $60 \mathrm{~min}$, postinjection in $\mathrm{d} 5+I+$ compared to $\mathrm{d} 5+I-$ and $\mathrm{d} 5-I-$ mice at both $2.0 \mathrm{mg} / \mathrm{kg}$ (Figure $3 \mathrm{~b})(p<0.0001)$ and $10.0 \mathrm{mg} / \mathrm{kg}$ (Figure 3c) $(p<0.0001)$.

Moreover, systemic administration of SKF 38393 at both doses significantly increased hippocampal ACh release in $\mathrm{d} 5+I+$ mice compared to saline injection $(p=0.0005$, $2.0 \mathrm{mg} / \mathrm{kg} ; p<0.0001,10.0 \mathrm{mg} / \mathrm{kg}$ ). In $\mathrm{d} 5-/-$, the administration of SKF 38393 did not increase hippocampal ACh release compared to saline. In $\mathrm{d} 5+I-$, a significant increase in ACh release was observed only following the administration of SKF 38393 at the higher dose used here $(p<0.0001)$ (Figure 3c).

Local perfusion of SKF $38393(10$ and $50 \mu \mathrm{M})$ directly through the dialysis probe significantly increased ACh release to 200 and $290 \%$ over basal values in the wild-type mice (Figure $4 \mathrm{a}, \mathrm{b}$ ), but only over 140 and $150 \%$ in $\mathrm{d} 5+I-$ mice (Figure $4 a, b$ ) while having no effect $d 5-/-$ mice (Figure $4 \mathrm{a}, \mathrm{b}$ ). Three-way ANOVA revealed a significant
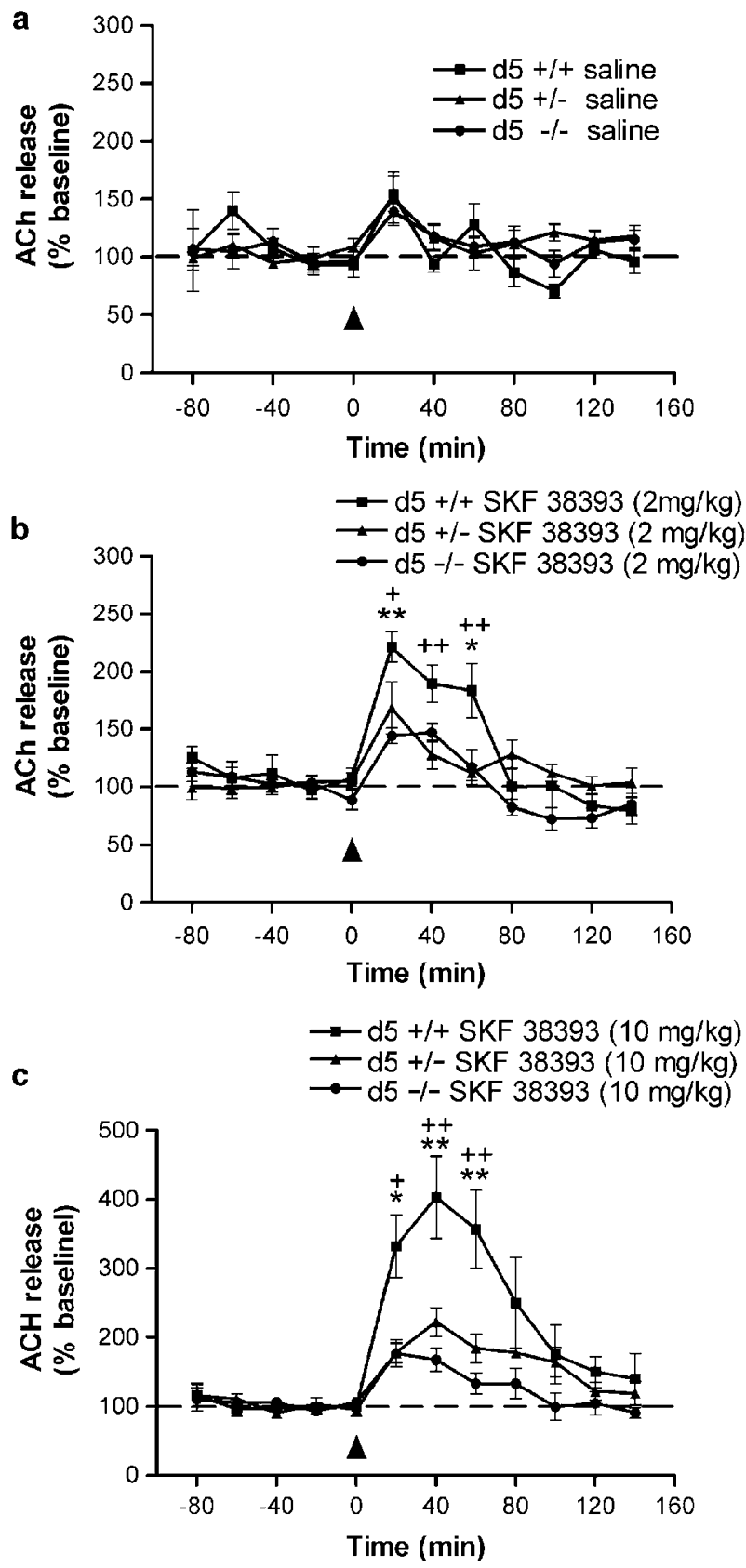

Figure 3 ACh release in the dorsal hippocampus in mice (d5-/-, d5 + /and $\mathrm{d} 5+/+$ ) following intraperitoneal administration of (a) saline solution, (b) SKF 38393 at $2.0 \mathrm{mg} / \mathrm{kg}$, and (c) SKF 38393 at $10.0 \mathrm{mg} / \mathrm{kg}$. Data represent mean $\pm \operatorname{SEM}(n=6-7$ in each group). Dialysate ACh content is expressed as percent of baseline. Baseline was calculated from the average of three samples preceding drug injection (arrow). For both doses, post hoc analysis revealed significant differences of drug effect between $\mathrm{d} 5+1+$ and $\mathrm{d} 5-1-$ : ** $p<0.001$; $* 2<0.01$ and between $\mathrm{d} 5+1+$ and $\mathrm{d} 5+1-$ : $+p<0.05 ;++p<0.01$

interaction between the main effects of genotype, treatment, and time $\left(\mathrm{F}_{(22,264)}=2.26, p=0.0001\right)$. A significant difference in hippocampal $\mathrm{ACh}$ release following stimulation with SKF 38393 is observed between $\mathrm{d} 5+I+$ and $\mathrm{d} 5-I-$ at both concentrations tested in this study $(p<0.0001$ for both concentrations) and a significant difference is observed between $\mathrm{d} 5+I-$ and $\mathrm{d} 5-I-$ only at $50 \mu \mathrm{M}(p=0.002)$. 

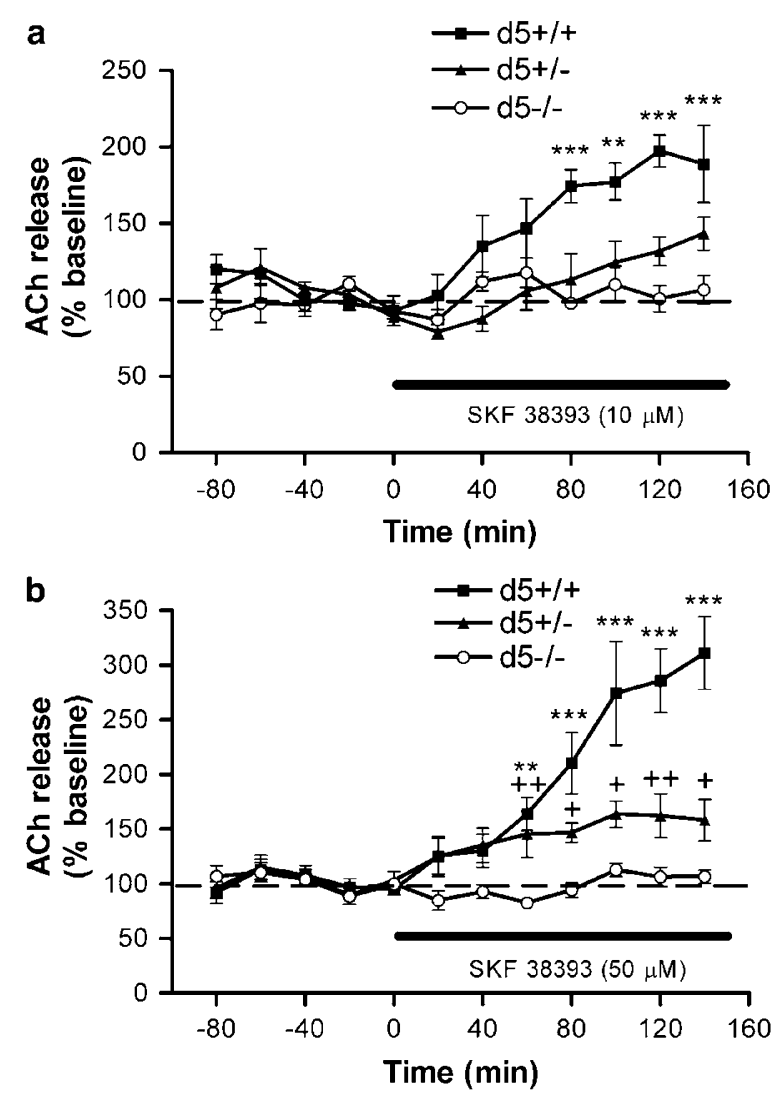

Figure 4 ACh release in the dorsal hippocampus in mice (d5-1-, d5 + /and $\mathrm{d} 5+/+$ ) following local perfusion of (a) $10 \mu \mathrm{M}$ and (b) $50 \mu \mathrm{M}$ SKF 38393. Data represent mean \pm SEM ( $n=5-6$ in each group). Dialysate ACh content is expressed as percent of baseline. Baseline was calculated from the average of three samples preceding drug perfusion (line). Post hoc analysis revealed significant differences of the drug effect between $\mathrm{d} 5+/+$ and $\mathrm{d} 5-1-$ : ${ }^{*} * p<0.01$; $* * * p<0.001$ and between $\mathrm{d} 5+1-$ and $\mathrm{d} 5-1-$ : $+p<0.05$; $++p<0.01$

\section{Quantitative Receptor Autoradiography}

Deletion of $\mathrm{d} 5$ receptors in $\mathrm{d} 5-/-$ mice resulted in significant reductions in specific $\left[{ }^{3} \mathrm{H}\right] \mathrm{SCH} 23390$ binding in all areas of the hippocampal formation $(50 \%$ in the dentate gyrus and $73 \%$ in other regions) compared to wild-type animals (Figure 5a, b) $(p<0.01)$. d5 $+I-$ mice exhibited intermediate declines in specific $\left[{ }^{3} \mathrm{H}\right] \mathrm{SCH} 23390$ binding (from 25 to $40 \%$ reduction; $p<0.05$ for CA3 subfield and $p<0.01$ for other regions) compared to wild-type animals.

Hippocampal $\left[{ }^{3} \mathrm{H}\right]$ pirenzepine $\mathrm{M}_{1}$-like and $\left[{ }^{3} \mathrm{H}\right]$ AFDX-384 $\mathrm{M}_{2}$-like muscarinic receptor binding sites are expressed in all subareas of the hippocampal formation (Figure 6a, c). Specific $\left[{ }^{3} \mathrm{H}\right]$ pirenzepine binding is significantly increased in all subregions of the hippocampal formation in the $\mathrm{d} 5$ knockout mouse (Figure 6b). Heterozygote mice displayed moderate increases in specific $\left[{ }^{3} \mathrm{H}\right]$ pirenzepine binding in the CA2 and CA3 subfields compared to $\mathrm{d} 5+I+$ (Figure 6b). Specific $\left[{ }^{3} \mathrm{H}\right]$ AFDX-384 $\quad \mathrm{M}_{2}$-like binding sites was not significantly changed in the three groups studied here (Figure 6d).

\section{DISCUSSION}

The main findings of the present study are that extracellular levels of hippocampal ACh are chronically decreased, a

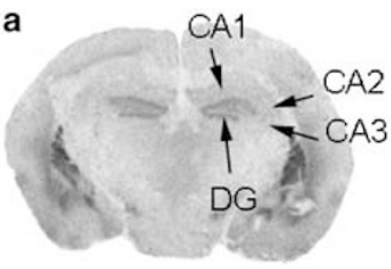

d5+/+

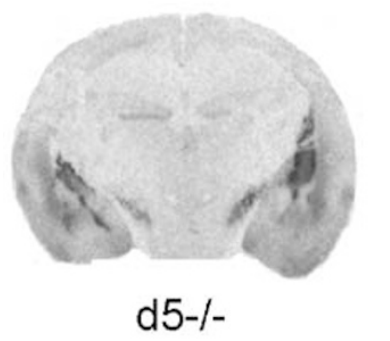

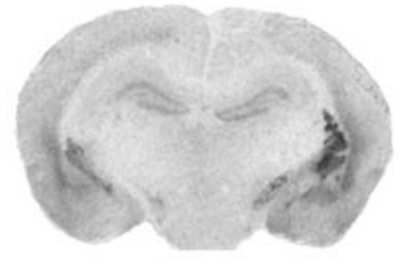

d5+/-

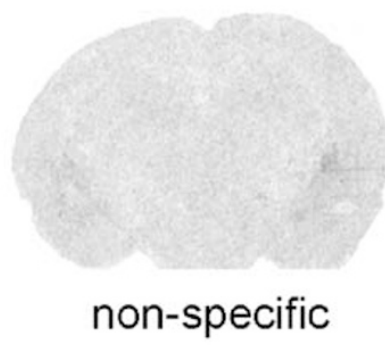

b

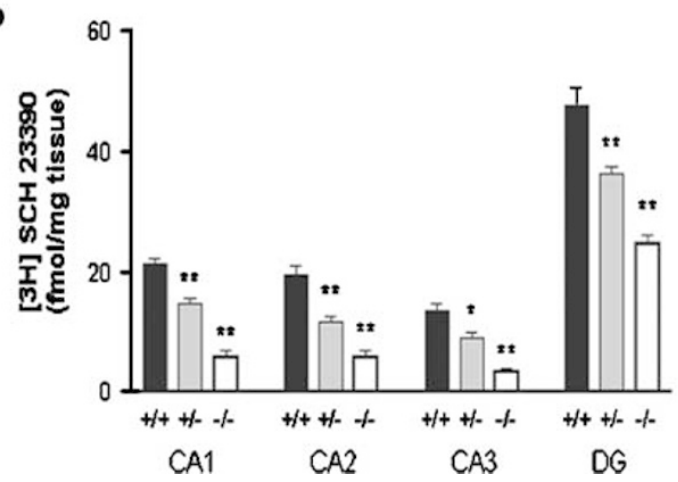

Figure 5 Quantitative autoradiography of $D_{1}$-like $D A$ receptor binding sites at the level of the hippocampal formation. (a) D,-like of dopaminergic receptors are known to be expressed in all subareas of the hippocampus. $\left[{ }^{3} \mathrm{H}\right] \mathrm{SCH} 23390$ exhibited $80 \%$ of specific binding in the normal mice. (b) $D_{1}$-like receptors were quantified in all genotypes. Data represent mean \pm SEM ( $n=6-8$ in each group). ANOVA with Dunnett's multiple comparisons revealed significant difference between $\mathrm{d} 5+1+$ and $\mathrm{d} 5+1-$ and between $\mathrm{d} 5+1+$ and $\mathrm{d} 5-1-$ : $* 0<0.05$; ** $p<0.01$. Abbreviations: Cal, Ca2, Ca3, subfields of the Ammon's horn of the hippocampus. DG, dentate gyrus.

and that a $\mathrm{DA} \mathrm{D}_{1}$-like agonist failed to modulate this release in the hippocampus of $\mathrm{d} 5$ receptor knockout mice. A blunted, but still significant effect was observed in heterozygous mice $(\mathrm{d} 5+/-)$ while SKF 38393 , the $\mathrm{D}_{1}$-like agonist, potentially facilitated ACh release in the hippocampus of wild-type mice. These results confirm and extend previous data mostly obtained in the rat suggesting that the $\mathrm{d} 5$ receptor subtype was the $\mathrm{D}_{1}$-like receptor involved in the regulation of hippocampal ACh release (Hersi et al, 1995a, 2000). The use of molecular approaches such as the one reported here based on knockout animals or oligonucleotide antisenses (Hersi et al, 2000) is required as currently available pharmacological tools cannot distinguish between $\mathrm{d} 1$ and $\mathrm{d} 5$ receptors, the two subtypes composing the $\mathrm{D}_{1}$-like family of DA receptors (Seeman and Van Tol, 1993; Sunahara et al, 1991). 

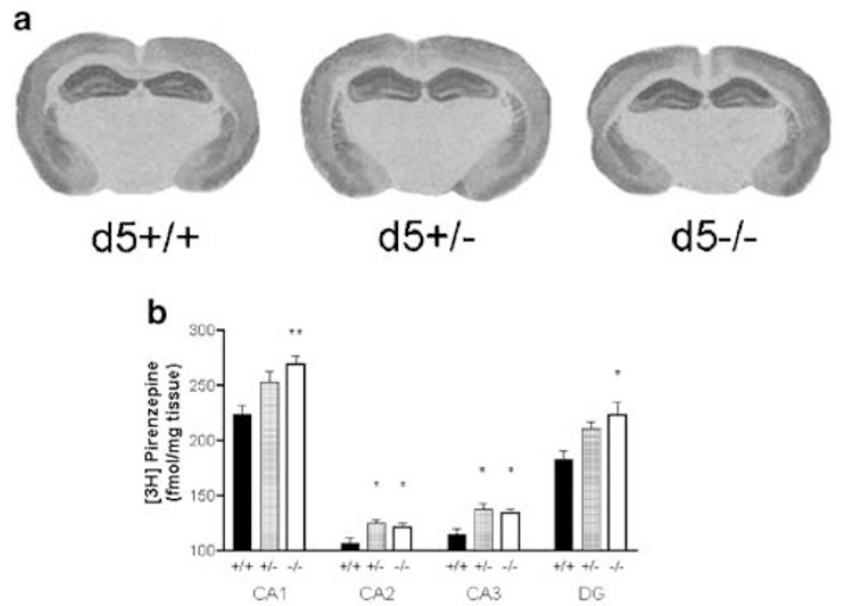

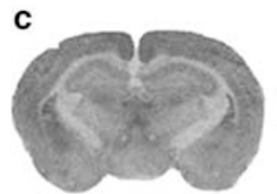

d $5+/+$

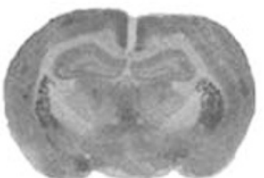

d5+/-

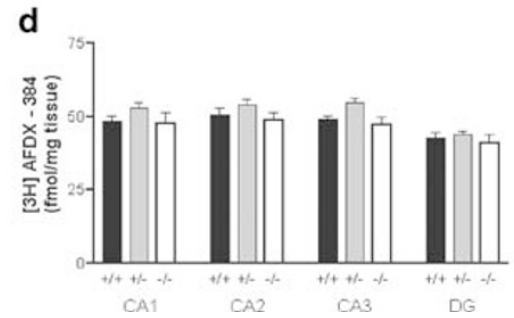

Figure 6 Quantitative autoradiography of muscarinic receptor binding sites in the hippocampal formation. Both $M_{1}$ and $M_{2}$-like muscarinic receptor classes are expressed in all subareas of the hippocampus. $\left[{ }^{3} \mathrm{H}\right]$ pirenzepine and $\left.{ }^{3} \mathrm{H}\right] \mathrm{AFDX} 384$ exhibited almost 100\% of specific binding. ( $a, b) M_{1}$-like and ( $c, d$ ) $M_{2}$-like muscarinic receptor binding sites were quantified in all genotypes. Data represent mean $\pm \operatorname{SEM}(n=7$ in each group). ANOVA with Dunnett's multiple comparisons revealed significant difference between $\mathrm{d} 5+1+$ and $\mathrm{d} 5+1-$ and between $\mathrm{d} 5+1+$ and d5-1-: *p $<0.05$; *** $<<0.01$. Abbreviations: Cal, Ca2, Ca3, subfields of the Ammon's horn of the hippocampus. DG, dentate gyrus.

In the $\mathrm{d} 5-/-$ mice, the lack of stimulatory effects of the $\mathrm{D}_{1}$-like agonist SKF 38393 on hippocampal ACh release was observed following systemic injections or intraprobe infusions of the agonist. In the heterozygous mice, significant effects of SKF 38393 were seen only at the higher concentration tested in this study, while the $\mathrm{D}_{1}$-like agonist potently facilitated in vivo hippocampal ACh release at both concentrations tested. These results are likely due to the loss of $\mathrm{D}_{1}$-like receptors in the hippocampal formation of $\mathrm{d} 5+I-$ and $\mathrm{d} 5-I-$ mice. Indeed, we observed that specific $\left[{ }^{3} \mathrm{H}\right] \mathrm{SCH} 23390 \mathrm{D}_{1}$-like receptor binding levels were significantly decreased in $\mathrm{d} 5$ knockout and heterozygous mice. The residual labelling seen in these animals is likely reflecting the presence of low but significant levels of $\mathrm{d} 1$ receptors in the hippocampus (Bergson et al, 1995; Tiberi et al, 1991). However, this class of receptors does not appear to be involved in the direct regulation of hippocampal ACh release as we failed to observe any effects of SKF 38393 in d5-/- animals. A previous study reported no reduction in specific $\left[{ }^{3} \mathrm{H}\right] \mathrm{SCH} 23390$ binding in the striatum; this is in accordance with the fact that this brain region is mostly enriched with d1 receptors (Hollon et al, 2002).

Anatomical evidence have shown that a subpopulation of hippocampal d5-like receptors are located on axons in the hippocampus (Bergson et al, 1995). Moreover, fimbriectomia resulted in significant losses in $\mathrm{D}_{1}$-like receptors in the dentate gyrus of the hippocampus (Hersi et al, 1995a). These data may be taken as evidences that $\mathrm{d} 5$ receptors are present on septo-hippocampal cholinergic nerve terminals where they can directly modulate ACh release.

Using the technique of 'no net flux' in vivo microdialysis (Justice, 1993), the calculated level of extracellular ACh was in the range of $4.4 \mathrm{nM}$ in the wild-type mouse dorsal hippocampus. This is comparable to the level reported in the rat dorsal hippocampus (Day et al, 2001). Interestingly, the basal level of ACh in the d5 knockout mouse $(2.8 \mathrm{nM})$ was significantly lower than in heterozygous $(4.0 \mathrm{nM})$ and wild-type ( $4.4 \mathrm{nM})$ mice. This result suggests that DA, acting though the $\mathrm{d} 5$ receptor, has a tonic role on the maintenance of normal ACh release in the hippocampus. Interestingly, the $\mathrm{d} 5$, but not $\mathrm{d} 1$, receptor subtype has been shown to be constitutively active even in the absence or in the presence of very low concentrations of DA (Tiberi and Caron, 1994; Demchyshyn et al, 2000). Such a constitutive activity could play a role in the maintenance of extracellular levels of ACh in the hippocampus.

What could be the functional relevance of hippocampal d5 receptors on the maintenance of normal release of $\mathrm{ACh}$ leading to enhanced extracellular levels? While it is well established that hippocampal cholinergic innervation plays a major role in attention and learning behaviors (Perry et al, 1999; Everitt and Robbins, 1997), the role of DA and dopaminergic receptors is not as clear, even if few studies have proposed that the $D_{1}$-like receptors can facilitate cognitive behaviors (Packard and White, 1991; Arnsten et al, 1994). In a recent study, Holmes et al (2001) reported normal spatial memory in $\mathrm{d} 5-/-$ mice in the Morris water maze, except for a minor deficit in hidden platform acquisition. Similar small deficits were seen in fear conditioning (Holmes et al, 2001). However, studies using pharmacological approaches have reported that $D_{1}$-like agonists can facilitate the late phase of long-term potentiation (LTP) and restore memory impairments in aged mice (Bach et al, 1999), and aged memory-impaired rats (Hersi et al, 1995b). Behavioral tests performed in d5-/- mice involved learning to avoid aversive stimuli (Holmes et al, 2001). It would thus be appropriate to investigate further the abilities of $\mathrm{d} 5-/-$ mice in attention and learning models that are more discriminating for various aspects of the cognitive process, such as reward-related memory mechanisms (Schultz et al, 1993). Also, a particular focus could be on attention as multiple studies have suggested a role for DA in attention behaviors over memory processes per se (Clark et al, 1987a, b; Nieoullon, 2002).

In addition to changes in extracellular ACh levels, increases in muscarinic $\mathrm{M}_{1}$-like, but not $\mathrm{M}_{2}$-like, receptors were found in the hippocampus of $\mathrm{d} 5-/-$ mice. $\mathrm{M}_{1}$-like receptors are mostly postsynaptically located in the hippocampus and are believed to be involved in LTP and in the maintenance of normal cognitive functions 
(Anagnostaras et al, 2003; Quirion et al, 1989). The increase in $\mathrm{M}_{1}$-like receptors may be a compensatory mechanism associated to the decrease in extracellular ACh levels found in this brain region in $\mathrm{d} 5$ knockout mice. This compensatory mechanism could also possibly explain the apparent lack of learning deficits of $\mathrm{d} 5-/-$ mice in the Morris water maze task (Holmes et al, 2001). On other hand, $\mathrm{M}_{2}$-like receptors are mostly presynaptic auto receptors exerting inhibitory effect on ACh release (Lapchak et al, 1989; Quirion et al, 1989).

In summary, deletion of the $\mathrm{d} 5$ receptor in a knockout mouse model results in a significant reduction in extracellular ACh levels in the hippocampal formation, suggesting a tonic role for this receptor in ACh release. Moreover, a $\mathrm{D}_{1}$-like agonist fails to stimulate in vivo $\mathrm{ACh}$ release in this model demonstrating further the unique role of the $\mathrm{d} 5$ receptor in the regulation of hippocampal ACh release. Further studies are now in progress to establish more precisely the behavioral relevance of these findings.

\section{ACKNOWLEDGEMENTS}

This work was supported by a grant from the Canadian Institutes of Health Research to RQ (CIHR). F Laplante holds a studentship from CIHR.

\section{REFERENCES}

Anagnostaras SG, Murphy GG, Hamilton SE, Mitchell SL, Rahnama NP, Nathanson NM et al (2003). Selective cognitive dysfunction in acetylcholine M1 muscarinic receptor mutant mice. Nat Neurosci 6: 51-58.

Araujo DM, Lapchak PA, Robitaille Y, Gauthier S, Quirion R (1988). Differential alteration of various cholinergic markers in cortical and subcortical regions of human brain in Alzheimer's disease. J Neurochem 50: 1914-1923.

Arnsten AF, Cai JX, Murphy BL, Goldman-Rakic PS (1994). Dopamine D1 receptor mechanisms in the cognitive performance of young adult and aged monkeys. Psychopharmacology (Berl) 116: 143-151.

Auld DS, Kornecook TJ, Bastianetto S, Quirion R (2002). Alzheimer's disease and the basal forebrain cholinergic system: relations to beta-amyloid peptides, cognition, and treatment strategies. Prog Neurobiol 68: 209-245.

Bach ME, Barad M, Son H, Zhuo M, Lu YF, Shih R et al (1999). Age-related defects in spatial memory are correlated with defects in the late phase of hippocampal long-term potentiation in vitro and are attenuated by drugs that enhance the cAMP signaling pathway. Proc Natl Acad Sci USA 96: 5280-5285.

Bergson C, Mrzljak L, Smiley JF, Pappy M, Levenson R, GoldmanRakic PS (1995). Regional, cellular, and subcellular variations in the distribution of D1 and D5 dopamine receptors in primate brain. J Neurosci 15: 7821-7836.

Clark CR, Geffen GM, Geffen LB (1987a). Catecholamines and attention. I: Animal and clinical studies. Neurosci Biobehav Rev 11: 341-352.

Clark CR, Geffen GM, Geffen LB (1987b). Catecholamines and attention. II: Pharmacological studies in normal humans. Neurosci Biobehav Rev 11: 353-364.

Davies P, Maloney AJ (1976). Selective loss of central cholinergic neurons in Alzheimer's disease. Lancet 2: 1403.

Day JC, Fibiger HC (1994). Dopaminergic regulation of septohippocampal cholinergic neurons. J Neurochem 63: 2086-2092.
Day JC, Kornecook TJ, Quirion R (2001). Application of in vivo microdialysis to the study of cholinergic systems. Methods 23: 21-39.

Dearry A, Gingrich JA, Falardeau P, Fremeau Jr RT, Bates MD, Caron MG (1990). Molecular cloning and expression of the gene for a human D1 dopamine receptor. Nature 347: 72-76.

Demchyshyn LL, McConkey F, Niznik HB (2000). Dopamine D5 receptor agonist high affinity and constitutive activity profile conferred by carboxyl-terminal tail sequence. J Biol Chem 275: 23446-23455.

Everitt BJ, Robbins TJ (1997). Central cholinergic systems and cognition. Ann Rev Psychol 48: 649-684.

Flores G, Wood GK, Liang JJ, Quirion R, Srivastava LK (1996). Enhanced amphetamine sensitivity and increased expression of dopamine D2 receptors in postpubertal rats after neonatal excitotoxic lesions of the medial prefrontal cortex. J Neurosci 16: 7366-7375.

Franklin KB, Paxinos G (1997). The Mouse Brain in Stereotaxic Coordinates. New York Academic Press: New York.

Gasbarri A, Verney C, Innocenzi R, Campana E, Pacitti C (1994). Mesolimbic dopaminergic neurons innervating the hippocampal formation in the rat: a combined retrograde tracing and immunohistochemical study. Brain Res 668: 71-79.

Hersi AI, Kitaichi K, Srivastava LK, Gaudreau P, Quirion R (2000). Dopamine D-5 receptor modulates hippocampal acetylcholine release. Brain Res Mol Brain Res 76: 336-340.

Hersi AI, Richard JW, Gaudreau P, Quirion R (1995a). Local modulation of hippocampal acetylcholine release by dopamine D1 receptors: a combined receptor autoradiography and in vivo dialysis study. J Neurosci 15: 7150-7157.

Hersi AI, Rowe W, Gaudreau P, Quirion R (1995b). Dopamine D1 receptor ligands modulate cognitive performance and hippocampal acetylcholine release in memory-impaired aged rats. Neuroscience 69: 1067-1074.

Hollon TR, Bek MJ, Lachowicz JE, Ariano MA, Mezey E, Ramachandran $\mathrm{R}$ et al (2002). Mice lacking D5 dopamine receptors have increased sympathetic tone and are hypertensive. J Neurosci 22: 10801-10810.

Holmes A, Hollon TR, Gleason TC, Liu Z, Dreiling J, Sibley DR et al (2001). Behavioral characterization of dopamine D5 receptor null mutant mice. Behav Neurosci 115: 1129-1144.

Imperato A, Obinu MC, Gessa GL (1993). Stimulation of both dopamine D1 and D2 receptors facilitates in vivo acetylcholine release in the hippocampus. Brain Res 618: 341-345.

Justice Jr JB (1993). Quantitative microdialysis of neurotransmitters. J Neurosci Methods 48: 263-276.

Kitaichi K, Day JC, Quirion R (1999). A novel muscarinic M(4) receptor antagonist provides further evidence of an autoreceptor role for the muscarinic M(2) receptor sub-type. Eur J Pharmacol 383: $53-56$.

Lapchak PA, Araujo DM, Quirion R, Collier B (1989). Binding sites for [3H]AF-DX 116 and effect of AF-DX 116 on endogenous acetylcholine release from rat brain slices. Brain Res 496: 285-294.

Levin ED, McGurk SR, Rose JE, Butcher LL (1990). Cholinergicdopaminergic interactions in cognitive performance. Behav Neural Biol 54: 271-299.

Mesulam MM, Mufson EJ, Wainer BH, Levey AI (1983). Central cholinergic pathways in the rat: an overview based on an alternative nomenclature (Ch1-Ch6). Neuroscience 10: 1185-1201.

Nieoullon A (2002). Dopamine and the regulation of cognition and attention. Prog Neurobiol 67: 53-83.

Packard MG, White NM (1991). Dissociation of hippocampus and caudate nucleus memory systems by posttraining intracerebral injection of dopamine agonists. Behav Neurosci 105: 295-306.

Perry E, Walker M, Grace J, Perry R (1999). Acetylcholine in mind: a neurotransmitter correlate of consciousness? Trends Neurosci 22: $273-280$. 
Perry EK, Johnson M, Kerwin JM, Piggott MA, Court JA, Shaw PJ et al (1992). Convergent cholinergic activities in aging and Alzheimer's disease. Neurobiol Aging 13: 393-400.

Quirion R, Aubert I, Lapchak PA, Schaum RP, Teolis S, Gauthier S et al (1989). Muscarinic receptor subtypes in human neurodegenerative disorders: focus on Alzheimer's disease. Trends Pharmacol Sci Suppl: 80-84.

Quirion R, Hammer Jr RP, Herkenham M, Pert CB (1981). Phencyclidine (angel dust)/sigma 'opiate' receptor: visualization by tritium-sensitive film. Proc Natl Acad Sci USA 78: 5881-5885.

Schultz W, Apicella P, Ljungberg T (1993). Responses of monkey dopamine neurons to reward and conditioned stimuli during successive steps of learning a delayed response task. J Neurosci 13: 900-913.

Seeman P, Van Tol HH (1993). Dopamine receptor pharmacology. Curr Opin Neurol Neurosurg 6: 602-608.

Steele TD, Hodges Jr DB, Levesque TR, Locke KW (1997). D1 agonist dihydrexidine releases acetylcholine and improves cognitive performance in rats. Pharmacol Biochem Behav 58: 477-483.

Steele TD, Hodges Jr DB, Levesque TR, Locke KW, Sandage Jr BW (1996). The D1 agonist dihydrexidine releases acetylcholine and improves cognition in rats. Ann N Y Acad Sci 777: 427-430.

Sunahara RK, Guan HC, O’Dowd BF, Seeman P, Laurier LG, Ng G et al (1991). Cloning of the gene for a human dopamine D5 receptor with higher affinity for dopamine than D1. Nature 350: 614-619.
Sunahara RK, Niznik HB, Weiner DM, Stormann TM, Brann MR, Kennedy JL et al (1990). Human dopamine D1 receptor encoded by an intronless gene on chromosome 5. Nature 347: 80-83.

Tiberi M, Caron MG (1994). High agonist-independent activity is a distinguishing feature of the dopamine D1B receptor subtype. J Biol Chem 269: 27925-27931.

Tiberi M, Jarvie KR, Silvia C, Falardeau P, Gingrich JA, Godinot N et al (1991). Cloning, molecular characterization, and chromosomal assignment of a gene encoding a second D1 dopamine receptor subtype: differential expression pattern in rat brain compared with the D1A receptor. Proc Natl Acad Sci USA 88: 7491-7495.

Vaucher E, Fluit P, Chishti MA, Westaway D, Mount HT, Kar S (2002). Object recognition memory and cholinergic parameters in mice expressing human presenilin 1 transgenes. Exp Neurol 175: 398-406.

Verney C, Baulac M, Berger B, Alvarez C, Vigny A, Helle KB (1985). Morphological evidence for a dopaminergic terminal field in the hippocampal formation of young and adult rat. Neuroscience 14: 1039-1052.

Woolf NJ (1991). Cholinergic systems in mammalian brain and spinal cord. Prog Neurobiol 37: 475-524.

Zhou QY, Grandy DK, Thambi L, Kushner JA, Van Tol HH, Cone R et al (1990). Cloning and expression of human and rat D1 dopamine receptors. Nature 347: 76-80. 